\title{
Non-Conventional Strategic Supply Chain Management towards Halal Perspective
}

Ariff Azly Muhamed, Mazuin Mat Halif, Mohd Zamri Abu Bakar, Mohd Faizul Hassan, Nur Najjah Abd Rahim

To Link this Article: http://dx.doi.org/10.6007/IJARBSS/v12-i1/12078 DOI:10.6007/IJARBSS/v12-i1/12078

Received: 09 November 2021, Revised: 11 December 2021, Accepted: 27 December 2021

Published Online: 18 January 2022

In-Text Citation: (Muhamed et al., 2022)

To Cite this Article: Muhamed, A. A., Halif, M. M., Bakar, M. Z. A., Hassan, M. F., \& Rahim, N. N. A. (2022). NonConventional Strategic Supply Chain Management towards Halal Perspective. International Journal of Academic Research in Business and Social Sciences, 12(1), 1454- 1477.

Copyright: @ 2022 The Author(s)

Published by Human Resource Management Academic Research Society (www.hrmars.com) This article is published under the Creative Commons Attribution (CC BY 4.0) license. Anyone may reproduce, distribute, translate and create derivative works of this article (for both commercial and non0-commercial purposes), subject to full attribution to the original publication and authors. The full terms of this license may be seen at: http://creativecommons.org/licences/by/4.0/legalcode

Vol. 12, No. 1, 2022, Pg. 1454 - 1477

Full Terms \& Conditions of access and use can be found at http://hrmars.com/index.php/pages/detail/publication-ethics 


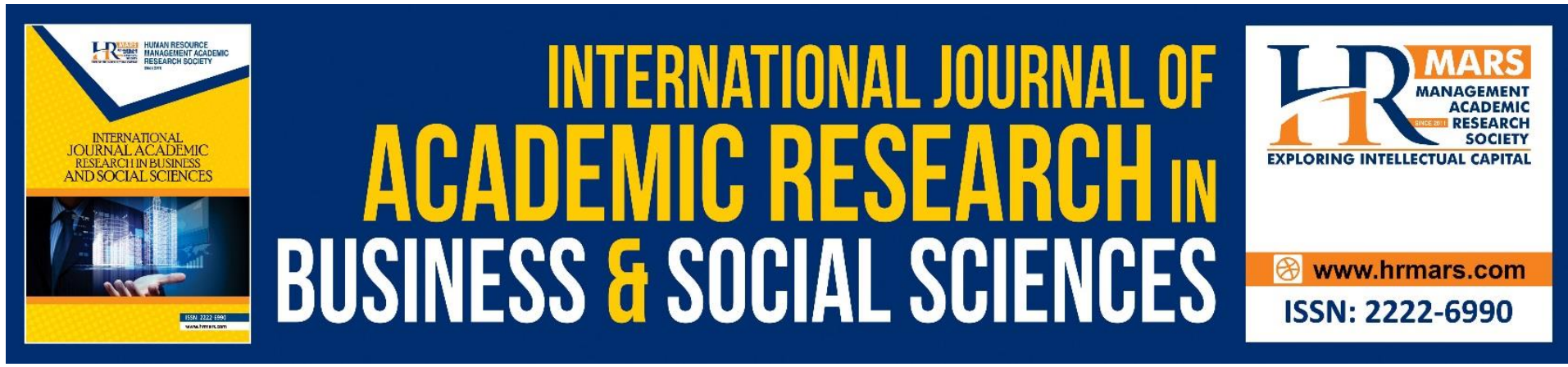

\title{
Non-Conventional Strategic Supply Chain Management towards Halal Perspective
}

\author{
Ariff Azly Muhamed, Mazuin Mat Halif, Mohd Zamri Abu Bakar, \\ Mohd Faizul Hassan, Nur Najjah Abd Rahim \\ Faculty of Business and Management, Universiti Teknologi MARA Puncak Alam, Selangor, \\ Malaysia \\ Corresponding Author Email: ariff@uitm.edu.my
}

\begin{abstract}
The implementations of halal concept into supply chain management have received great attention due to the increasing demand for halal products. It is necessary for manufacturers to establish firm's strategic orientation includes supply chain orientation and market orientation to sustain firm competitiveness in emerging halal market. Therefore, this study aims to conduct a systematic literature review to identify the state of the art of the halal studies in supply chain area. The review protocol was involving 249 research articles. Based on a review of previous studies, this paper improves the existing framework of the halal supply chain by incorporating strategic orientation and halal's firm performance. Therefore, this paper contributes the strategic approach to preserving the integrity of halal while sustain the firm performance.
\end{abstract}

Keywords: Halal, Supply Chain Management, Strategic Orientation, Market Orientation, Supply Chain Orientation, Systematic Review

\section{Introduction}

Currently, the terminology of halal becomes popular among Muslims and non-Muslims due to its labeled as the new symbol of quality in products and services. Halal is an Arabic term means permitted, allowed, lawful, or legal in respect of lifestyle, food consumption, banking, and manufacturing. Its opposite is haram which means forbidden, unlawful or illegal (Alam \& Sayuti, 2011; Awan et al., 2015; Eliasi \& Dwyer, 2002; Muhammad et al., 2009; Poniman et al., 2015; Rosly, 2010; Tieman, 2011, 2013a). Explicitly, halal is a concept to ensure and maintain the quality of the various activities and practices by Muslims in their daily life including business activities. In today's business activities, manufacturing of the halal products involves a various party in the process.

The halal marketplace is one of the successful and influential business arenas in today (Muhammad et al., 2009) world halal trade which is increasing gradually $f 30$ billion per year (Ahmed, 2008). Large halal marketplaces are strongly related to the increasing worldwide Muslim population which represents $25 \%$ (1.8billion) of the world population (Adams, 2011; Poniman et al., 2015) and expected to increase to 2.1 billion population in 2030 (Zulfakar, et 
al., 2015). The increasing of the Muslim's population triggers halal market to expand since Muslims are compulsory to consume the halal products. Furthermore, Haque \& Sarwar (2015) report that the non-Muslim consumers are likely to consume halal products due to the excellent quality of the halal products itself.

The various parties involved in handling halal products will lead to the issue of halal integrity of the product. Recently, the consumer concern not only about the manufacturing process but also the supply chain of the products (Omar \& Jaafar, 2011). There are two important factors for a firm to practicing Syariah compliance supply chain management. Firstly, Syariah compliance of supply chain management or known as halal SCM is crucial for a firm to obtain halal certification. Secondly, it is essential for a firm to practicing halal concept in SCM in a view to penetrating the worldwide market especially in a country which majority of the population are Muslims. Zailani et al (2015) found that most of the halal firms are small and medium enterprises (SMEs). The fact brings a question on how the firm wants to implement halal practice due to the scarcity of resources strategically. The shortage of resources in implementing halal SCM has been pointed out by Talib et al (2015) including knowledge, facilities, financial, and lack of government support. Thus, the next study is necessary to provide a solution for a firm to incorporate halal SCM in its operations without neglecting its performance as the halal SCM can be a double-edged sword if firm unable to strategize it properly.

Understanding resources and capacity to implement halal practice in supply chain management and to ensure the firm performance and sustainable growth may depend on firm's orientation towards halal and SCM issue. When investigating business practice outcome, critical variable, competitive performance, and competitive behavior are strongly influenced by strategic organizational orientation (Kirchoff et al., 2016; Noble et al., 2002). Mello \& Stank (2005) emphasize on the strategic orientation which guides the firm conduct, value, and firm's internal decision making in the supply chain. Furthermore, Ngah, Zainuddin, \& Thurasamy (2014) contend that to ensure the halal compliance; a firm must encompass the strategic orientation in its operation. Thus, it is important to determine to what extent the strategic orientation plays a role in a firm that practicing halal concept.

Adoption of halal concept into conventional supply chain management is an innovation towards conventional supply chain of new products and services, a new production technology that encompassed Syariah requirement into the process (Kamaruddin \& Udin, 2009; Ngah et al., 2014a). The literature report that firm performance are strongly related to the innovation (Karabulut, 2015; Paik \& Chang, 2014; Saunila et al., 2014). However, there is a lack of study on the impact of firm's strategic orientation towards service innovation and firm's performance (Theodosiou et al., 2012). It is important to know the impact of halal firm's strategic orientation towards firm's performance since Talib, Hamid, \& Chin (2015) mention that the halal firms have a limitation in term of skill and knowledge in implementing halal certification. Zailani et al (2015) emphasize that halal firms will not become competitive if the firms only declare halal certified, but failed to have a niche of the production operation. This evidence strengthens the hypothesis that firm need to employ their available resources to become competitive strategically.

A firm's difficulties in terms of financial and operation in incorporating halal SCM, along with the competitive advantage is a significant motivation for the two objectives of this study. Firstly, this study aims to introduce the idea of the systematic review technique to explore the state of the art of halal SCM. Secondly, this study focuses on proposing a new model based 
on the literature and expanding the existing model by integrating strategic orientation and firm's performance.

The remainder of this article has three parts. Part one is a systematic literature review of halal SCM in analyzing the current state of halal SCM. The review protocols such as bibliographic analysis and publication background are in a view to identifying the trends of the study among scholars and understanding the concept of halal SCM comprehensively. Part two demonstrates the discussion and outline of the halal SCM and strategic orientation. Part three is on proposition and model development of strategic orientation impact towards halal SCM and firm performance. It is essential to note that this is the first study using systematic literature review in assessing the importance of strategic orientation in halal SCM and firm performance. This study contributes significantly to the knowledge gap as well as halal industry practitioners by providing a foundation for implementing halal supply chain management in an effort to increase firm efficiency through the identification of strategic orientations possessed.

\section{Material and Method}

This study employed systematic literature review methodology to identify, critically evaluate, and summarize relevant, high-quality article of halal SCM to fully understand and integrate research in a particular study as proposed by Littell, Corcoran, \& Pillai (2008). Further, the research question of this study is inspired by Tranfield, Denyer, \& Smart (2003) which emphasize that systematic review is an effective method to develop a research question and inform empirical research practices

The review provides interdisciplinary and comprehensive understanding about halal supply chain management and strategic orientation. The authors believe that the halal supply chain is a subject of an investigation under the philosophical view. The present literature of halal supply chain is limited to exploratory study. Systematic review involved outlook on the research questions, assemble literature guideline development, determine on inclusion and exclusion criteria, develop a comprehensive search plan for finding literature, developed match word for the label and explaining literature, code the literature, and understand the literature (Tranfield et al., 2003). The next sub-section discussed the step-by-step systematic literature review in detail.

\section{Research Question, Database, Website and Relevance Search Term}

The databases used for the literature search are from the major publishers such as Elsevier (www.sciencedirect.com) and Emerald (www.emeraldinsight.com). Tranfield et al (2003) suggest that search should not restrict to a bibliographic database. Thus, the application of Google Scholar was such an assistant to search unpublished study, proceeding, and conference.

The simple literature search used term "halal," "supply chain management," and "strategic orientation." Later the advance search with the word "AND" was used to combine each search term to understand the state of the current research on each topic clearly. Moreover, the search period is from 2010-2016 to ensure the articles and studies were upto-date.

\section{Applying Practical Screening Material}

Research paper, conference paper, proceeding paper, and research report were all included with time restriction from the year 2010 till 2016. The initial inclusion criteria were 
broadened to include the entire relevant articles in the topic were peer reviewed articles and published in English to avoid any language bias. Empirical and conceptual research papers were accepted, but, presentation, book review, and comment were excluded to ensure the quality criteria. Some publications regarding the halal product, halal services, and intention to purchase halal product also were included to give a better understanding of the halal supply chain relationship. The entire selected published articles were an available article in the web database. Witell, Snyder, Gustafsson, Fombelle, \& Kristensson (2016) suggest that the scope of the search was not limited to any particular field, the subject of research, or journal but a full overview of the research topic. Stechemesser \& Guenther (2012) contend that journal ranking should not be used as an exclusion criterion, as the aim of the review was to give a better understanding of halal SCM and strategic orientation. All the articles were under the category of life-science instead of food technology. Surprisingly, many of the publication focused on the science field which related to a halal ingredient in food. As such, these kinds of articles were not on the list for the review.

\section{Methodological Screening Criteria}

In performing systematic and translucent literature review, a development of review protocol was essential for the content analysis to be a powerful tool (Ahi \& Searcy, 2014; Seuring \& Gold, 2012). The review protocol (Table 1) consists of four sections in which the first section encompassed the bibliographic of each publication. The second section consisted of the background of publication such as the methodology used in a particular article, either empirical study, conceptual/ theoretical or literature review article. The third section focused on the definition or description of the halal supply chain and strategic orientation. This article has initially analyzed the explicit and implicit definition of halal SCM, and strategic orientation. The fourth section determined the construct of halal SCM and strategic orientation. The next sub-topic discussed the result of synthesizing finding.

Table 1 Example of review protocol

\begin{tabular}{|c|c|c|}
\hline \multicolumn{3}{|l|}{ Bibliographic data } \\
\hline Author & Who is the publication's author & Zailani et al. \\
\hline Year & $\begin{array}{l}\text { In which year the publication of the } \\
\text { article? }\end{array}$ & 2015 \\
\hline Title & What is the title of the publication? & $\begin{array}{l}\text { Drivers of halal } \\
\text { orientation strategy } \\
\text { among halal food } \\
\text { firm }\end{array}$ \\
\hline $\begin{array}{l}\text { Affiliation of the } \\
\text { Author }\end{array}$ & $\begin{array}{l}\text { What is the first author's institutional } \\
\text { background? }\end{array}$ & Malaysia, Academic \\
\hline Origin of the Author & $\begin{array}{l}\text { What is the first author's geographic } \\
\text { origin? }\end{array}$ & Malaysia \\
\hline Type of Publication & What is the type of publication? & Research paper \\
\hline Journal Name & What is the journal name? & British Food Journal \\
\hline ISI- Impact (2014) & $\begin{array}{l}\text { What is the ranking of the journal in } \\
\text { 2014? }\end{array}$ & 0.772 \\
\hline \multicolumn{3}{|c|}{ Background of Publication } \\
\hline $\begin{array}{l}\text { The Methodology of } \\
\text { the Publication }\end{array}$ & $\begin{array}{l}\text { What is the related method in the } \\
\text { publication/research? }\end{array}$ & Empirical survey \\
\hline
\end{tabular}


Country

Industries
In which country the publication/research was carried out?

Which industries are the subjects to the publication?

\section{Result and Analysis}

The review protocol (Table 1) presents the structure of this section. Firstly, it discussed the bibliographic analyses of the database search and followed by the definition and previous study. The section of discussion demonstrated the construct of halal SCM and two type of strategic orientation.

\section{Bibliographic Analysis}

The database search of search term of halal yield 1037 publications, where Elsevier $(\mathrm{N}=726)$ and Emerald $(\mathrm{N}=311)$. As illustrated in Figure 1, the increasing number of publication with the highest in the year 2014 and 2015. This kind of statistic showed that the halal study was becoming necessary and increased the interest in the academic research. In respect of this study, there was a filter of, inclusion and exclusion screening criteria for selecting the relevant articles which are in line with the scope of the research. After the first integration, Elsevier yields 141 publications where the exclusion of 585 publications while Emerald yield 108 publication where the exclusion of 203 articles. The total excluded publication was 788 articles. After the first screening criteria, the total selected publications were 249 articles

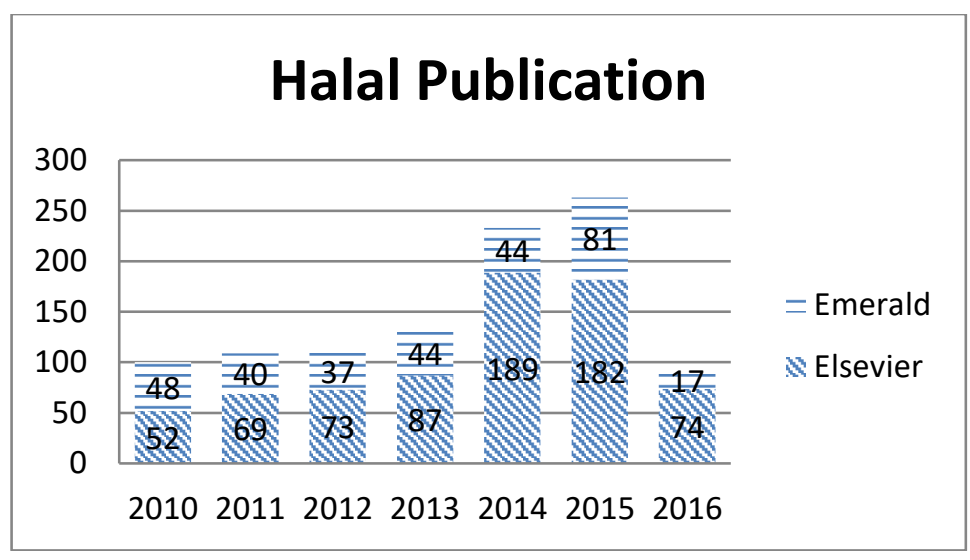

Figure 1 Halal publication 2010 -2016 


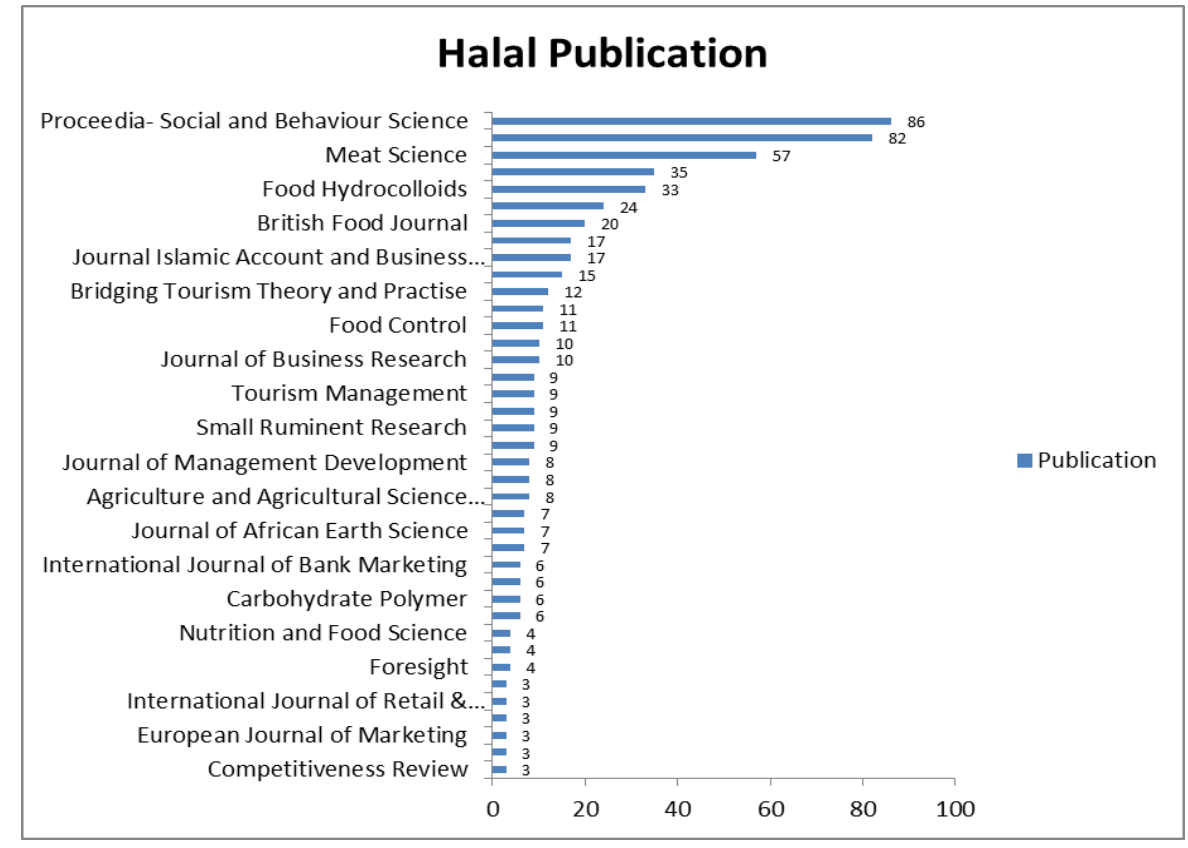

Figure 2 Journal and Proceeding of halal

The review of all the selected publications was on the first author's affiliation and origin. If the author was not from academic field, the category was under practitioner. The breakdown of the first author's affiliation compilation showed the $95 \%$ of academic and $5 \%$ of the practitioner. The field of the research was from business and management (38\%), followed by science (36\%) and social science (26\%). The first authors were from Asia (85\%), Europe $(10 \%)$, and Middle East (5\%). Surprisingly, even though the majority of the Middle East populations are Muslims, but the research of halal in the region was comparatively lower than Europe and Asia. The finding showed that the research on halal SCM did not only focus on the Asian region but from a different perspective of halal SCM itself.

This study focused on two types of publication namely journals (85\%), and proceeding and conference paper (15\%). In fact, analyzing the detail of selected journal is important (Stechemesser \& Guenther, 2012). In summary, Figure 2 presents the breakdown of 39 journals and proceedings

Regarding the significant of journal's quality, there was a discussion on the ISI-impact factor. Based on the screening of all journals for ISI-impact factor; the highest ISI-impact factor recorded was 1.865 for business and management studies, while science and social science research was 4.09 and 2.554 respectively. Meanwhile, 25 journals had no impact factor but with Scopus indexed. The range of non-science journals with ISI-impact factor was from 0.772 to 1.865 .

Based on the bibliographic analysis, even though the business and management journals were the highest contributors to the publication, its ISI-impact factor was still relatively lower compared to the science study. In such a situation, a thorough in halal SCM research was necessary. The finding from the bibliographic analysis found that the research on halal was becoming famous in the Europe (Ahmed, 2008; Bonne et al., 2008; Hassan \& Awang, 2009). The next subchapter analyzed all the publications' background by the review protocol. 


\section{Publication Background}

This section analyzed the methodology of the pool of the reference articles. The categories of the items were according to the type of methodology such as conceptual, theoretical, and empirical. Empirical research papers were namely literature review, market survey, and case study. The next analyzing was on origin country of the research. The final analyzing of the articles was on the type of industries either the research on the specific industry or nonindustry specification. Table 2 summarizes all those analyses.

Table 2 shows that empirical research dominated approximately $71 \%$ of the publications while the rest $29 \%$ were conceptual and theoretical study. The survey research dominated the empirical cluster. As mentioned in earlier, Asia region such as Malaysia, Indonesia, and Brunei contributed most of the publications. In fact, all those countries are Muslims majority population. Additionally, analyzing of the pool of publications on the type of industry-specific focus found that the major contributions to the publication were $50 \%$ in respect of food and beverages. This finding was in line with Tieman and Nistelrooy (2014) which point out that halal terms are a synonym to foods and beverages.

Based on the publication background analysis; there was still insufficient research both in the conceptual and empirical approach of research of halal SCM. However, a quantitative survey was a popular approach in the literature body of the most of the halal research. The finding also showed that halal logistic was still in the early stage of halal research, which only contributed $35 \%$ of the publication. Ngah et. al (Ngah et al., 2015) emphasize that halal integrity depends on the halal logistic issues such as warehouse and transportation. Thus, the next section discussed the halal SCM in detail for comprehensive understanding.

Table 2 Publication background summary

\begin{tabular}{|c|c|c|c|c|c|c|c|c|c|c|}
\hline \multirow[t]{2}{*}{ Author } & \multirow[t]{2}{*}{ Year } & \multicolumn{2}{|c|}{ Methodology } & \multirow[b]{2}{*}{ Country } & \multicolumn{5}{|c|}{ Industries } & \multirow[b]{2}{*}{$f$} \\
\hline & & $\begin{array}{l}\text { Conceptua } \\
\text { I }\end{array}$ & $\begin{array}{l}\text { Empirica } \\
\text { I }\end{array}$ & & a & b & c & d & e & \\
\hline Alserhan & 2010 & $\mathbf{V}$ & & Europe & & & & & & \\
\hline $\begin{array}{l}\text { Haq and } \\
\text { Wong }\end{array}$ & 2010 & & $\sqrt{ }$ & Australia & & $\sqrt{ }$ & & & & \\
\hline $\begin{array}{l}\text { Wilson and } \\
\text { Liu }\end{array}$ & 2010 & $\sqrt{ }$ & & - & & & & & & \\
\hline Adams & 2011 & $\boldsymbol{V}$ & & - & & & & & & \\
\hline Ahmad et al. & 2011 & & $\sqrt{ }$ & - & & & $\sqrt{ }$ & & & \\
\hline $\begin{array}{l}\text { Alam and } \\
\text { Sayuti }\end{array}$ & 2011 & & $\boldsymbol{v}$ & Malaysia & $\sqrt{ }$ & & & & & \\
\hline $\begin{array}{l}\text { Bahrudin et } \\
\text { al. }\end{array}$ & 2011 & & $\boldsymbol{v}$ & Malaysia & $\boldsymbol{v}$ & & & & & \\
\hline $\begin{array}{l}\text { Ireland and } \\
\text { Rajabzadeh }\end{array}$ & 2011 & & $\sqrt{ }$ & UAE & $\sqrt{ }$ & & & & & \\
\hline Jaafar et al. & 2011 & & $\boldsymbol{V}$ & Malaysia & & & & $\sqrt{ }$ & & \\
\hline Nasir et al. & 2011 & & $\sqrt{ }$ & Malaysia & $\boldsymbol{v}$ & & & & & \\
\hline $\begin{array}{l}\text { Omar and } \\
\text { Jaafar }\end{array}$ & 2011 & $\sqrt{ }$ & & Malaysia & $\boldsymbol{v}$ & & & & & \\
\hline
\end{tabular}




\begin{tabular}{|c|c|c|c|c|c|c|c|}
\hline Tieman & 2011 & & $\mathbf{v}$ & $\begin{array}{c}\text { Malaysia } \\
\text { and } \\
\text { Brunei }\end{array}$ & & $\mathbf{v}$ & \\
\hline $\begin{array}{l}\text { Hamdan et } \\
\text { al. }\end{array}$ & 2012 & & $\mathbf{v}$ & Malaysia & $\boldsymbol{V}$ & & \\
\hline $\begin{array}{l}\text { Talib and } \\
\text { Johan }\end{array}$ & 2012 & $\mathbf{V}$ & & Malaysia & $\mathbf{V}$ & & \\
\hline Tieman & 2012 & & $\sqrt{ }$ & $\begin{array}{l}\text { Malaysia } \\
\text { China } \\
\text { Netherlan } \\
\text { d }\end{array}$ & $\mathbf{v}$ & & \\
\hline $\begin{array}{l}\text { Abdul-Talib } \\
\text { and Abd- } \\
\text { Razak }\end{array}$ & 2013 & $\mathbf{V}$ & & - & & & \\
\hline $\begin{array}{l}\text { Butt and } \\
\text { Aftab }\end{array}$ & 2013 & & $\mathbf{v}$ & Pakistan & & & $\mathbf{v}$ \\
\hline Tieman & 2013 & & $\mathbf{v}$ & $\begin{array}{c}\text { Malaysia } \\
\text { Netherlan } \\
\text { d }\end{array}$ & $\mathbf{V}$ & $\mathbf{v}$ & \\
\hline Tieman & 2013 & & $\mathbf{V}$ & Malaysia & & $\mathbf{V}$ & \\
\hline $\begin{array}{l}\text { Tieman and } \\
\text { Ghazali }\end{array}$ & 2013 & $\mathbf{V}$ & & - & & & \\
\hline Hamid et al. & 2014 & $\mathbf{V}$ & & - & & $\boldsymbol{V}$ & \\
\hline $\begin{array}{l}\text { Karia and } \\
\text { Asaari }\end{array}$ & 2014 & $\mathbf{v}$ & & Malaysia & & $\mathbf{V}$ & \\
\hline Ngah et al. & 2014 & & $\sqrt{ }$ & Malaysia & $\mathbf{V}$ & $\mathbf{v}$ & $\mathbf{v}$ \\
\hline Ngah et al. & $\begin{array}{c}2014 \\
a\end{array}$ & & $\sqrt{ }$ & & $\mathbf{V}$ & $\mathbf{v}$ & $\boldsymbol{v}$ \\
\hline $\begin{array}{l}\text { Talib and } \\
\text { Hamid }\end{array}$ & 2014 & $\mathbf{V}$ & & Malaysia & & $\boldsymbol{V}$ & \\
\hline $\begin{array}{l}\text { Talib and } \\
\text { Hamid }\end{array}$ & $\begin{array}{c}2014 \\
b\end{array}$ & & $\mathbf{v}$ & Malaysia & & $\mathbf{V}$ & \\
\hline $\begin{array}{l}\text { Tieman and } \\
\text { Nistelrooy }\end{array}$ & 2014 & & $\mathbf{V}$ & Malaysia & $\mathbf{V}$ & $\mathbf{V}$ & \\
\hline $\begin{array}{l}\text { Aoun and } \\
\text { Tournois }\end{array}$ & 2015 & & $\mathbf{V}$ & Europe & & & $\mathbf{v}$ \\
\hline Aris et al. & 2015 & & $\mathbf{v}$ & Indonesia & & & $\boldsymbol{v}$ \\
\hline Awan et al. & 2015 & & v & Pakistan & $\boldsymbol{V}$ & & \\
\hline $\begin{array}{l}\text { Haque and } \\
\text { Sarwar }\end{array}$ & 2015 & & v & Malaysia & $\boldsymbol{V}$ & & \\
\hline Karia et al. & 2015 & & $\mathbf{V}$ & Malaysia & & $\mathbf{v}$ & \\
\hline $\begin{array}{l}\text { Khalek and } \\
\text { Ismail }\end{array}$ & 2015 & & $\mathbf{v}$ & Malaysia & $\mathbf{V}$ & & \\
\hline Ngah et al. & 2015 & & $\mathbf{v}$ & Malaysia & & $\boldsymbol{V}$ & \\
\hline $\begin{array}{l}\text { Poniman et } \\
\text { al. }\end{array}$ & 2015 & & $\mathbf{v}$ & Australia & $\boldsymbol{V}$ & & \\
\hline
\end{tabular}




\begin{tabular}{|c|c|c|c|c|c|}
\hline $\begin{array}{l}\text { Talib, } \\
\text { Hamid, and } \\
\text { Chin }\end{array}$ & 2015 & & $\boldsymbol{v}$ & - & $\boldsymbol{v}$ \\
\hline $\begin{array}{l}\text { Talib, } \\
\text { Hamid, and } \\
\text { Zulfakar }\end{array}$ & 2015 & & v & - & \\
\hline $\begin{array}{l}\text { Talib, } \\
\text { Hamid, } \\
\text { Zulfakar et } \\
\text { al. }\end{array}$ & 2015 & & V & Malaysia & \\
\hline Tieman & 2015 & $\sqrt{ }$ & & $\begin{array}{c}\text { Malaysia } \\
\text { UAE }\end{array}$ & $\mathbf{v}$ \\
\hline $\begin{array}{l}\text { Tieman and } \\
\text { Hassan }\end{array}$ & 2015 & $\sqrt{ }$ & & - & $\boldsymbol{v}$ \\
\hline Zailani et al. & 2015 & & $\mathbf{v}$ & Malaysia & $\mathbf{v}$ \\
\hline
\end{tabular}

\section{Halal Supply Chain Management}

Supply chain management (SCM) is a philosophy for managing the interdependence among supply network (Lambert \& Cooper, 2000; Nunen et al., 2005; Reefke \& Trocchi, 2013; Svensson, 2007). On the other hand, there is the difference between conventional supply chain management and halal SCM, which halal SCM concerns about managing supply chain strictly by Syariah compliance while considering the cost reduction and firm performance of the supply chain key player. In comparing halal and conventional supply chain, Bahrudin et al. (2011) mention that conventional supply chain management focuses on cost reduction and maximizing profit along with the supply chain while halal SCM focuses on ensuring the halal integrity of the product to the end-user along with the downstream supply chain. As mentioned earlier, possibilities of cross contamination occur are high if one of the supply chain key players does not practice halal concept in the firm's operation. Due to that, a comprehensive understanding of halal SCM is essential for a better of halal practice. Zailani et al (2015) mention that $53.3 \%$ of the halal-certified companies belongs to the non-Muslims. In respect of SME businesses that have a limitation in strategic implementation for a long-run company profits, halal practice might be a focus and motivation. However, Vlajic, Van Der Vorst \& Haijema ( 2012) mention that robustness of supply chain is a key point in ensuring firm's performance.

Tieman (2011) contends that robustness of halal SCM is compulsory to protect the halal purity and quality of the product under uncertainty environment. Robustness in the SCM literature is mainly on the capability of the system to well-functioning in the event of an interruption (Dong, 2006; Tang, 2006; Vlajic et al., 2012; Waters, 2007). A further study by Tieman (2012) presents two indicators of halal SCM robustness, namely a halal testing and process quality (Abdul-Matin, 2010; Bonne \& Verbeke, 2008; Khalili-Damghani et al., 2015), and adequate access to dedicated halal warehouses and halal transport/container whenever required. The additional study underlines on the implementation of information technology (IT) such as Radio Frequency Identification (RFID) as one alternative for halal SCM robustness (Anir et al., 2008; Brown \& Russell, 2007; Nasir et al., 2011; Wang et al., 2010; Wu \& Ku, 2013). However, all the proposed methods in the literature require high financial investment. 
From the discussion, it is noticeable that halal SCM required a high investment capital to achieve a robust halal SCM and enhance the integrity of halal. Thus, it is important for a firm to govern strategic orientation as a firm competitive strategy to attain a sustainable halal supply chain.

\section{Strategic Orientation}

Deutscher et al (2016) reflect strategic orientation (SO) as a principle that directs the marketing strategies (Noble et al., 2002; Wimalachandra et al., 2014) of a firm and generates the behavior intended (Gatignon \& Xuereb, 1997; Ho et al., 2015) in ensuring its viability and performance. In fact, the literature defined SO as a strategic management of a firm to fully utilized the available resources to create a superior performance. Moreover, there is a question on why strategic orientation is critical in implementing halal SCM which made a necessary to overview the available strategic typologies in the existing literature.

There are a variety of typologies that discussed the business strategies feasibility. Miles et al (1978) focus on the process of organization's dynamic in adapting ambiguous environment changes (Masoumi et al., 2015; O'Regan \& Ghobadian, 2005) while Porter (1980) describes on strategic positioning of the firm. However, Rugman \& Verbeke (1988); O'Regan \& Ghobadian (2005) point out that Porter's model are not compatible with SME due to the ability of SME to adopt a focused strategy only. Miles and Snow's strategic typologies propose four types of firm's strategy such as prospector, defender, analyzer, and reactor.

It is important for the halal practicing firms to identify which strategy to be implemented to sustain firm's competitiveness and performance without compromising halal integrity. Talib et al (2015) show that major limitation for the firms in implementing halal is a lack of market recognization and implementation cost. These two barriers indicate that halal certified companies have the obligatory to find an effective way to overcome those limitations. This opinion also shared by Ho et al (2015) who emphasize the necessary of strategic orientation for the firm's competitive advantage.

In addition, the literature shows the interest of complimenting two orientations namely market orientation and supply chain orientation (Day \& Lichtenstein, 2006; Esper et al., 2010; Min et al., 2007; Min \& Mentzer, 2004). The literature demonstrates that firms which focus only to single strategic orientation will tend to have poor firm performance (Hakala, 2011; Kumar et al., 2011; Laukkanen et al., 2013). Market orientation drives firms to fulfill internal and external customer need as the primary goal. Likewise, supply chain orientations are the philosophy of the firm to manage supply chain key player while ensuring the product are punctually delivered to the customer with a shorter period, with a high quality, and minimum cost involved. Wisner (2003) point out the objective of the supply chain is to reduce system-wide cost while maintaining required service level.

In above discussion, it portrayed that halal supply chain key player was necessary to determine the firm's strategic orientation to sustain competitiveness in the emerging halal market. Gunasekaran et al (2008) accentuate that failure in regulating the strategic orientation may lead to inefficient halal manufacturing, thus may impact the firm performance and competitiveness. Thus, it is salience for the halal supply chain key player to focus on the supply chain as a firm's competitive strategy to escalate the firm performance while preserving halal integrity across the supply chain.

6. SUPPLY CHAIN ORIENTATION 
Mentzer et al (2001) define supply chain orientation (SCO) as a firm's recognition of the systematic and strategic implications of the activities and processes involved in managing supply chain (Esper et al., 2010; Miocevic \& Crnjak-Karanovic, 2012). By definition, SCO is a strategic management view of a firm to implement an effective supply network between the supply chain key players. Min \& Mentzer (2004) argue that before a firm can effectively occupy in the strategic management of supply chain process, it must first look inward.

Possess SCO in halal SCM was very crucial. The fact was due to the halal status of the product depended on the complete key players among the halal SCM. A halal product's manufacturer could not obtain a halal certification if the raw material supplier did not practice halal standard in their operation process. A study by Tieman (2013b) elaborates that halal supply chain is the course of managing the procurement, movement, storage, and handling of materials, parts, livestock, semi-finished or finished inventory both food and non-food, and related information and documentation flows through the organization and the supply chain in compliance with the general philosophies of Shariah (Talib et al., 2015).

In the earliest study by Min and Mentzer (Min \& Mentzer, 2004), it is vital for supply chain oriented firm to build and maintain a cultural element of relationships such as trust, top management support, cooperative norms, commitment, and organizational compatibility within the supply chain network. These cultural elements were in line with Ngah et al (2014b) and Hamid et al (2014) which stress that the top management support is positively related to the adoption of halal supply chain and increased the service quality. Instead of top management support, a commitment to the players in halal SCM also is obligatory.

Many companies have adopted various supply chain management practice, such as Just-InTime (JIT), supplier development, and joint planning to gain a competitive advantage in the marketplace, all of which demand close cooperation among supply chain member (Cai et al., 2011; Dong et al., 2001; Heide \& John, 1992; Krause, 1999). Cooperation between supply chain key players depended on the firm's commitment. Despite looking on the buyer-seller commitment, there was a need to look for the internal engagement of the firm. The literature emphasized that it is crucial to building commitment through trust between supply chain key players (Chang et al., 2015; Stanko et al., 2007). Doney \& Cannon (1997) mention in the earliest study; many firms build a collaborative relationship with the customers and suppliers in responding to the competitive market which requires the firm to be more creative and flexible. Even though supply chain orientation seemed necessary for a halal firm to increase company's profit, on the other hand, the market also played a crucial role in determining the firm's performance. Thus, the next section discusses the importance of market orientation strategy on halal SCM.

\section{Market Orientation}

The previous study has confirmed the positive relationship between the market orientation (MO) and business performance (Theodosiou et al., 2012). Wei, Zhao, \& Zhang (2014) mention that market orientation is critical in strategic orientation. By definition, $\mathrm{MO}$ is the organization-wide generation of market intelligence about current and future customer needs, dissemination of intelligence across the department, and organization-wide responsiveness to it (Jaworski \& Kohli, 1996; Koc, 2011; Kohli \& Jaworski, 1990). Deshpande, Farley \& Webster (1993); Min et al (2007) reflect MO as a set of beliefs that focus the customer interest first, including all stakeholders such as owners, managers, and employees, to develop a long-term profitable enterprise. Despite the different perspective of definition 
by previous literature, the ultimate goal of the market orientation is to gain a sustainable profit by putting the market need as a precedence.

Having said that, Salavou, Baltas, \& Lioukas (2004) mention that there is a little attention and focus on the relationship between $\mathrm{MO}$ and innovation. In the research by Jaworski \& Kohli (1996), the authors contend that there is an absence of the innovation in the market orientation despite a need for an outcome of the market orientation. Based on the literature, halal SCM is an innovation towards the conventional SCM.

MO in halal SCM is a critical factor in ensuring the halal firm sustained its competitiveness in the marketplace. Slater \& Narver (2000) describe that market-oriented firms are more innovative due to high responsiveness to rapidly evolving customer needs. Hamdan et al (2012) argue that customer purchased intention of the halal product depends on consumers' perception towards the product, awareness, and halal knowledge. Investigation of the previous studies on the halal product purchasing intention using the theory of planned behavior (TPB) as a theoretical model (Alam \& Sayuti, 2011; Bonne et al., 2007; Haque et al., 2015) empirically prove that attitude and perceived behavior play a significant role towards halal product purchased. This finding shows that higher intentions towards halal product purchase depend on the society awareness towards the advantage of consuming the halal product.

The fact that $\mathrm{MO}$ components have a significant relationship on innovation (Abdul-Talib \& Abd-Razak, 2013; Grinstein, 2008) is contrary to the findings by Zhou et al (2005) which argues that overemphasized on the MO will stunt the research and development (R\&D) activity, and slow down the introduction of the new innovative product to the marketplace. Min et al (2007) reveal that although many kinds of literature found a positive relationship between $\mathrm{MO}$ and firm's performance, then again some studies report that weak or lack of association relationship between $\mathrm{MO}$ and firm's performance. Thus, it is still a puzzle on the necessary to complement MO with other strategic orientations (Hurley \& Hult, 1998; Marinova et al., 2008; Menguc, 2006; Muhamed et al., 2020; Theodosiou et al., 2012). In the context of halal SCM, $\mathrm{MO}$ is a very crucial factor in penetrating emerging halal market. Somehow, it is still an issue of whether MO has a significant relationship with halal firm's performance with the presence of halal SCM as a mediating role.

There is a possible mediating role of SCM concept in the MO-firm's performance link (Min et al., 2007). In the recent studies by Lee et al (2015) there are three indicators of MO namely intelligence generation (Zarco et al., 2011), intelligence dissemination, and integrated response. Based on the literature review, the next chapter discussed the development of the model and proposition.

\section{Model and Preposition}

This section introduced the model and proposition that integrated the SCO, MO, and halal SCM. A finding from the literature review showed that SO is the essence of the halal supply chain performance and firm's performance. In fact, such finding determined the role of SO in the halal supply chain business process. The introduction of the model in this research appeared as an extended example of the relationship between halal SCM and performance of the halal supply chain. The proposed model improves the previous model of Tieman (2012) where it has a merit as a basis for the model development, but it does not reflect the outcomes of implementing halal practice in SCM. Furthermore, the lack of theoretical approach in the previous model leads to an extension by way of incorporating theoretical 
approach into the model. In summary, this study extends Tieman (2012) research regarding the following:-

Extending halal supply chain practice to include a new construct strategic orientation and firm's performance;

Specifying a research model and proposition based on strategic orientation and halal supply chain practices;

Extending the performance construct to include firm's performance; and

Encompassed a theoretical approach into the halal SCM model.

The result from literature study, it is found that a solid research proposition is raised in model development. It includes SCO, MO, and the halal SCM practice. The following propositions were developed to explain the relationship between the variable.

Supply Chain Orientation and halal SCM practice

Min \& Mentzer (2004) find a relationship between SCO and supply chain practice. The study aligns with Mentzer et al. (2001) which emphasize on the implementation of supply chain practice which needs SCO in their firms. However, the studies do not consider the moderating effect of market orientation as Muhammad et al. (2009) mention that halal SCM's relationship should be looked heterogeneously whereby a successful halal SCM practice requires two or more constructs, as the following proposition:

\section{P1: Supply Chain Orientation is positively related to the adoption of halal SCM}

Market Orientation and Halal SCM Practice

A study by Min et al (2007) argues that MO has a significant relationship to the firm's performance whenever SCO is under control. Moreover, Zhou et al (2005) contend that MO significantly affects halal SCM, which mediates the FP. Jaafar et al (2011); Ngah et al (2014b) opine that halal supply chain is an innovation towards the conventional supply chain. It is evident from the literature that MO significantly impacts the halal SCM practices, and develops the following proposition:

\section{P2: Market Orientation is positively related to the adoption of halal SCM}

Market Orientation and Supply Chain Orientation alignment

Theodosiou et al (2012) highlight that firms could maximize their performance by complementing market orientation with other important strategic orientation that fit their environmental contexts and organizational characteristics. Other empirical research shows that the combination of one or more strategic orientation essences will improve the innovation and enhance the firm's performance (Deutscher et al., 2016; Tutar et al., 2015; Zarco et al., 2011). Such evidence builds the following propositions:

P3: market orientation and supply chain orientation alignment have a relationship towards halal supply chain management

The following proposition can be illustrated in Figure 3 where $\mathrm{MO}$ and SCO are the independent variables which have a causal relationship towards the halal SCM practice in 
industries. This is in line with the finding of Kirchoff et al (2016) which stressed that the MO and SCO are vital in the implementation of services innovation such as halal SCM in industries.

The following mathematical representation proves the relationship between the alignment of $\mathrm{MO}$ and SCO as Equation 1, where variable $Y$ is dependent variable (DV) which is halal SCM and $\mathrm{X}=$ Market Orientation (MO) and Z=Supply Chain Orientation (SCO). SCO and MO are the essences of SO. It is important to investigate the relationship between innovation and SO (O'Regan \& Ghobadian, 2005) and the relationship between innovation and firm's performance (Karabulut, 2015; Lii \& Kuo, 2016; Ngo \& O'Cass, 2013; Wang et al., 2015)

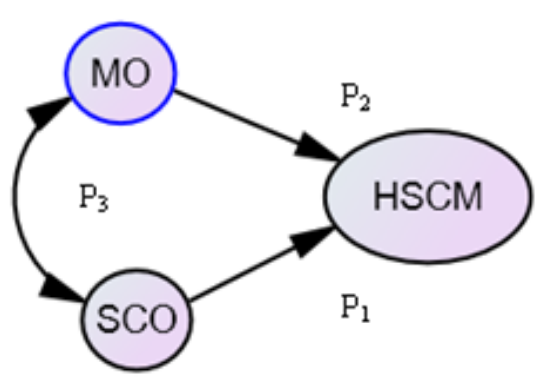

Figure 3 Proposed research model using fit-as -moderation

$$
Y=f(X, Z, X . Z)
$$

The proposed model as shown in Figure 3 relates the strategic orientation and halal supply chain management practices. The hypothesis shows that the firm performance can be sustained by the presence of the halal SCM as a mediator. Thus, the following proposition can be made and illustrated in Figure 4.

1) Halal Supply Chain Management - Strategic Orientation - Firm Performance (FP)

Theodosiou et al (2012) point out that it is important to investigate the role of intervening variable that mediates the relationship between strategic orientation and performance outcome. The literature emphasizes the necessary to inquire into the relationship between one essence of strategic orientation with other complimentary orientation such as innovation, organizational learning, quality, productivity, and entrepreneurship (Hurley \& Hult, 1998; Marinova et al., 2008; Menguc, 2006; Muhamed et al., 2019; Theodosiou et al., 2012; Zhou et al., 2005). Such relationship develops the following proposition and illustrated in Figure 4: 
$\mathrm{P}_{4}$ : halal SCM mediate the relationship between SO and FP

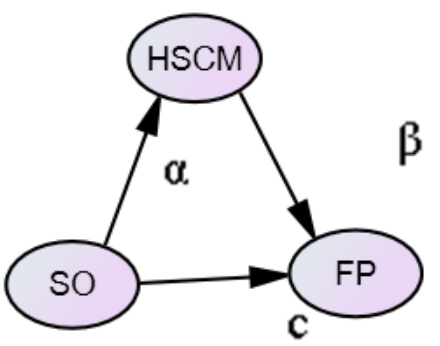

Figure 4 Proposed model based on fit-as-mediation perspective

. The mathematical equation below (2-4) and the proposition model as shown in Figure 4, represent the relationship between variables, whereby $c$ is a direct effect, and $\alpha \beta$ is an indirect effect.

$$
\begin{gathered}
F P=i+c S O+e 1 \\
H S C M=i+\alpha S O+e 2 \\
F P=i+c^{\prime} S O+\beta H S C M+e 1
\end{gathered}
$$

From all above discussion and proposition, it is clear that in order to sustain the firm performance, the $\mathrm{MO}$ and SCO are salience in order to overcome the barrier such as resources scarcity issue. This is also been highlight by Paik \& Chang (2014) which stress MO and SCO is one of the internal resources that form need to employ in order to generate and sustained the competitive advantage to implement halal SCM.

\section{Summary and Future Work}

This study aimed to highlight the important construct of halal SCM, aligned with strategic orientation approached based on RBV theory and its impacts towards firm's performance. Moreover, this study developed a proposed model and proposition for further empirical research.

In fact, integration of market orientation and supply chain orientation expanded the halal SCM framework. Furthermore, there was also a refinement of the proposed model to include the alignment of the market and supply chain orientation and the impact towards innovation. More importantly, this study is the pioneer in incorporating RBV perspective towards the halal SCM management hence enhance and broaden the body of knowledge of halal study.

In propositioning the relationship of supply chain orientation and market orientation towards halal SCM, the authors argued that market orientation inhibits towards the innovativeness of the firm (Tutar et al. [110]). In fact, there must be a consideration of the strategic orientation as a moderating variable. Based on Min et al. [84], the authors contended that the state $\mathrm{MO}$ was an antecedent of SCO and $\mathrm{MO}$ was a foundation in managing the supply chain. The alignment of SCO and MO worked together towards the firm's competitive advantages and innovativeness. The new construct of the strategic construct and innovativeness provides complex inter-relationship between the strategic orientation, 
innovativeness and firm performance. The empirical study of the proposed model would contribute a new insight to the knowledge of strategic orientation, halal SCM, and FP.

The result of this study would provide a significant contribution in confirming the relationship of the halal SCM towards FP by the strategic alignment of market orientation and supply chain orientation. The finding would show a clear direction towards firms and academic since the incorporation of strategic orientation would enhance the firm's innovativeness and performance.

The survey research would provide an early attempt towards the study. It guides for a detailed research by incorporating the different types of strategic orientation from an Islamic point of view. It is a hope that this study would support future research on the financial and operational performance. In this view, the application of the interdisciplinary study approach is relevant since it would direct to the same objective. Future research also needs to consider the quantitative approach and technique as it will confirm the developed proposition.

\section{References}

Abdul-Matin, I. (2010). Grren Dean: What Islam Teaches About Protecting the Planet.

Abdul-Talib, A., \& Abd-Razak, I. (2013). Cultivating export market oriented behavior in halal marketing. Journal of Islamic Marketing, 4(2), 187-197. https://doi.org/10.1108/17590831311329304

Adams, I. A. (2011). Globalization: Explaining the dynamics and challenges of the halal food surge. Intellectual Discourse, 19(1), 123-145. https://doi.org/10.4103/2045080X.123209

Ahi, P., \& Searcy, C. (2014). An Analysis of Metrics Used to Measure Performance in Green and Sustainable Supply Chains. Journal of Cleaner Production, 86, 360-377. https://doi.org/10.1016/j.jclepro.2014.08.005

Ahmad, H., Fazullah, A., Borham, A. J., \& Hashim, H. (2011). Halal Studies In Universities : A Way Forward To Manage Halal Introduction to Fundamental Halal Halal Industry and Awareness. International Jornal of Arts and Sciences Conference, 1-9.

Ahmed, A. (2008). Marketing of halal meat in the United Kingdom: Supermarkets versus local shops. British Food Journal, 110(7), 655-670. https://doi.org/10.1108/00070700810887149

Alam, S. S., \& Sayuti, N. M. (2011). Applying the Theory of Planned Behavior (TPB) in halal food purchasing. International Journal of Commerce and Management, 21(1), 8-20. https://doi.org/10.1108/10569211111111676

Alserhan, B. A. (2010). On Islamic branding: brands as good deeds. Journal of Islamic Marketing, 1(2), 101-106. https://doi.org/10.1108/17590831011055842

Anir, N., Nizam, M., \& Masliyana, A. (2008). RFID tag for Halal food tracking in Malaysia: users perceptions and opportunities. ... and Computers in ..., 5(5), 87-92. http://www.wseas.us/e-library/conferences/2008/istanbul/tele-info/tele-info_14.pdf

Aoun, I., \& Tournois, L. (2015). Building holistic brands: an exploratory study of Halal cosmetics. Journal of Is/amic Marketing, 6(1), 109-132. https://doi.org/10.1108/JIMA05-2014-0035

Aris, A. T., Zzaman, W., Yang, T. A., \& Harivaindaran, K. (2015). Is There a Market for Istihalah Food Product in Indonesia?: Knowledge, Attitute, and Practices towards Istihalah among Students in an Indonesian University. Journal of Islamic Marketing, 6(3), 377-387.

Awan, H. M., Siddiquei, A. N., \& Haider, Z. (2015). Factor affecting Halal purchase intention - 
evidence from Pakistan's Halal food sector. Management Research Review, 38(6), 640660.

Bahrudin, S. S. M., Illyas, M. I., \& Desa, M. I. (2011). Tracking and tracing technology for halal product integrity over the supply chain. Proceedings of the 2011 International Conference on Electrical Engineering and Informatics, ICEEI 2011, July. https://doi.org/10.1109/ICEEI.2011.6021678

Bonne, K., \& Verbeke, W. (2008). Religious values informing halal meat production and the control and delivery of halal credence quality. Agriculture and Human Values, 25(1), 35-47. https://doi.org/10.1007/s10460-007-9076-y

Bonne, K., Vermeir, I., Bergeaud-Blackler, F., \& Verbeke, W. (2007). Determinants of halal meat consumption in France. British Food Journal, 109(5), 367-386. https://doi.org/10.1108/0070700710746786

Bonne, K., Vermeir, I., \& Verbeke, W. (2008). Impact of Religion on Halal Meat Consumption Decision Making in Belgium. Journal of International Food \& Agribusiness Marketing, 21(1), 5-26. https://doi.org/10.1080/08974430802480628

Brown, I., \& Russell, J. (2007). Radio frequency identification technology: An exploratory study on adoption in the South African retail sector. International Journal of Information Management, 27(4), 250-265. https://doi.org/10.1016/j.ijinfomgt.2007.02.007

Butt, M. M., \& Aftab, M. (2013). Incorporating attitude towards Halal banking in an integrated service quality, satisfaction, trust and loyalty model in online Islamic banking context. International Journal of Bank Marketing, 31(1), 6-23.

Cai, S., Yang, Z., \& Jun, M. (2011). Cooperative norms, structural mechanisms, and supplier performance: Empirical evidence from Chinese manufacturers. Journal of Purchasing and Supply Management, 17(1), 1-10. https://doi.org/10.1016/j.pursup.2009.12.006

Chang, W., Ellinger, A. E., Kim, K. (Kate), \& Franke, G. R. (2015). Supply chain integration and firm financial performance: A meta-analysis of positional advantage mediation and moderating factors. European Management Journal. https://doi.org/10.1016/j.emj.2015.11.008

Day, M., \& Lichtenstein, S. (2006). Strategic supply management: The relationship between supply management practices, strategic orientation and their impact on organisational performance. Journal of Purchasing and Supply Management, 12(6 SPEC. ISS.), 313321. https://doi.org/10.1016/j.pursup.2007.01.005

Deshpande, R., Farley, J. U., \& Webster, F. E. (1993). Corporate Culture, Customer Orientation, and Innovativeness in Japanese Firms - a Quadrad Analysis. Journal of Marketing, 57(1), 23-27. https://doi.org/10.2307/1252055

Deutscher, F., Zapkau, F. B., Schwens, C., Baum, M., \& Kabst, R. (2016). Strategic orientations and performance: A configurational perspective. Journal of Business Research, 69(2), 849-861. https://doi.org/10.1016/j.jbusres.2015.07.005

Doney, P. M., \& Cannon, J. P. (1997). An Examination of the Nature of Trust in Buyer-Seller Relationships. Journal of Marketing, 61(April), 35-51. https://doi.org/10.2307/1251829

Dong, M. (2006). Development of supply chain network robustness index. International Journal of Services Operations and Informatics, 1, 54-66. https://doi.org/10.1504/IJSOI.2006.010189

Dong, Y., Carter, C. R., \& Dresner, M. E. (2001). JIT purchasing and performance: An exploratory analysis of buyer and supplier perspectives. Journal of Operations Management, 19(4), 471-483. https://doi.org/10.1016/S0272-6963(00)00066-8 
Eliasi, J. R., \& Dwyer, J. T. (2002). Kosher and Halal. Journal of the American Dietetic Association, 102(7), 911-913. https://doi.org/10.1016/S0002-8223(02)90203-8

Esper, T. L., Defee, C. C., \& Mentzer, J. T. (2010). A framework of supply chain orientation. The International Journal of Logistics Management, 21(2), 161-179. https://doi.org/10.1108/09574091011071906

Gatignon, H., \& Xuereb, J.-M. (1997). Strategic New Orientation of Product the Firm and. American Marketing Association, 34(1), 77-90.

Grinstein, A. (2008). The effect of market orientation and its components on innovation consequences: A meta-analysis. Journal of the Academy of Marketing Science, 36(2), 166-173. https://doi.org/10.1007/s11747-007-0053-1

Gunasekaran, A., Lai, K. H., \& Cheng, E. T. C. (2008). Responsive supply chain: A competitive strategy in a networked economy. Omega, 36(4), 549-564. https://doi.org/10.1016/j.omega.2006.12.002

Hamdan, H., Mat Issa, Z., \& Abu, N. (2012). Purchasing Decisions among Muslim Consumers of Processed Halal Food Products Purchasing Decisions among Muslim Consumers of Processed Halal Food Products. Journal of Food Products Marketing, 19(November 2013), 54-61. https://doi.org/10.1080/10454446.2013.724365

Hamid, A. B. A., Talib, M. S. A., \& Mohamad, N. (2014). Ḥalāl logistics : A marketing mix perspective. Intellectual Discourse, 22(2), 191-214.

http://journals.iium.edu.my/intdiscourse/index.php/islam/article/view/562/505

Haq, F., \& Wong, H. Y. (2010). Is spiritual tourism a new strategy for marketing Islam? Journal of Islamic Marketing, 1(2), 136-148. https://doi.org/10.1108/17590831011055879

Haque, A., Sarwar, A., Yasmin, F., Tarofder, A. K., \& Hossain, M. A. (2015). Non-Muslim consumers' perception toward purchasing halal food products in Malaysia. Journal of Islamic Marketing, 6(1), 133-147. https://doi.org/10.1108/JIMA-04-2014-0033

Hassan, W. M. W., \& Awang, K. W. (2009). Halal Food in New Zealand Restaurants : An Exploratory Study. International Journal of Economics and Management, 3(2), 385-402. https://doi.org/10.1300/J047v15n01

Heide, J. B., \& John, G. (1992). Do Norms Matter in Marketing Relationships? Journal of Marketing, 56(2), 32-44. https://doi.org/10.2307/1252040

Ho, J., Plewa, C., \& Lu, V. N. (2015). Examining strategic orientation complementarity using multiple regression analysis and fuzzy set QCA. Journal of Business Research. https://doi.org/10.1016/j.jbusres.2015.12.030

Hurley, R. F., \& Hult, G. T. M. (1998). Innovation, Learning : An Organizational and Empirical Integration Examination. Journal of Marketing, 62(3), 42-54.

Ireland, J., \& Rajabzadeh, S. A. (2011). UAE consumer concerns about halal products. Journal of Islamic Marketing, 2(3), 274-283. https://doi.org/10.1108/17590831111164796

Jaafar, H. S., Endut, I. R., Faisol, N., \& Omar, E. N. (2011). Innovation in logistic services-halal logistic. Proceeding of the 16th International Symposium on Logistic, 47061.

Jaworski, B. J., \& Kohli, A. K. (1996). Market orientation: Review, refinement, and roadmap. Journal of Market-Focused Management, 1(2), 119-135. https://doi.org/10.1007/BF00128686

Kamaruddin, N. K., \& Udin, Z. M. (2009). Supply chain technology adoption in Malaysian automotive suppliers. Journal of Manufacturing Technology Management, 20(3), 385403. https://doi.org/10.1108/17410380910936819

Karabulut, A. T. (2015). Effects of Innovation Types on Performance of Manufacturing Firms 
in Turkey. Procedia - Social and Behavioral Sciences, 195, 1355-1364.

https://doi.org/10.1016/j.sbspro.2015.06.322

Karia, N., Abu Hassan Asaari, M. H., Mohamad, N., \& Kamaruddin, S. (2015). Assessing Halal logistics competence: An Islamic-based and resource-based view. 2015 International Conference on Industrial Engineering and Operations Management (IEOM), 1-6. https://doi.org/10.1109/IEOM.2015.7093744

Karia, N., \& Asaari, M. H. A. (2014). Developing Halal Logistics Framework: An Innovation Approach. Vision 2020: Sustainable Growth, Economic Development, and Global Competitiveness, Vols 1-5, MAY 2014, 328-334.

Khalek, A. A., \& Ismail, S. H. S. (2015). Why Are We Eating Halal - Using the Theory of Planned Behavior in Predicting Halal Food Consumption among Generation $Y$ in Malaysia. International Journal of Social Science and Humanity, 5(7), 608-612. https://doi.org/10.7763/IJSSH.2015.V5.526

Khalili-Damghani, K., Tavana, M. C., \& Najmodin, M.(2015). Reverse logistics and supply chains: A Structural equation modeling investigation. International Journal of Industrial Engineering: Theory Applications and Practice, 22(3), 354-368. http://www.scopus.com/inward/record.url?eid=2-s2.084957006608\&partnerID=40\&md5=44871c56d1dba804f9b856ca2eddf98f

Kirchoff, J. F., Tate, W. L., \& Mollenkopf, D. (2016). The impact of strategic orientation organizational orientation on green supply chain management and firm performance. International Journal of Physical Distribution \& Logistics Management, 46(3), 269-292.

Koc, T. (2011). The Relationship Between TQM and Performance in Small Manufacturing Enterprises : The Mediation Effect of Failure. 18(4), 203-218.

Kohli, A. K., \& Jaworski, B. J. (1990). Market orientation: the construct, research propositions, and managerial implications. Journal of Marketing, 54(2), 1-18. http://search.ebscohost.com/login.aspx?direct=true\&db=epref\&AN=JM.FI.BD.KIRCA.M O\&lang=fr\&site $=$ bsi-live

Krause, D. R. (1999). The antecedents of buying firms' efforts to improve suppliers. Journal of Operations Management, 17(2), 205-224. https://doi.org/10.1016/S02726963(98)00038-2

Lambert, D. M., \& Cooper, M. C. (2000). Issues in Supply Chain Management. Industrial Marketing Management, 29, 65-83.

Lee, Y.-K., Kim, S.-H., Seo, M.-K., \& Hight, S. K. (2015). Market orientation and business performance: Evidence from franchising industry. International Journal of Hospitality Management, 44, 28-37. https://doi.org/10.1016/j.ijhm.2014.09.008

Lii, P., \& Kuo, F.-I. (2016). Innovation-oriented supply chain integration for combined competitiveness and firm performance. International Journal of Production Economics. https://doi.org/10.1016/j.ijpe.2016.01.018

Littell, J. H., Corcoran, J., \& Pillai, V. (2008). Systematic Review and Meta-Analysis. In Oxford University Press (Vol. 5, Issue 2).

Marinova, D., Ye, J., \& Singh, J. (2008). Do Frontline Mechanisms Matter? Impact of Quality and Productivity Orientations on Unit Revenue, Efficiency, and Customer Satisfaction. Journal of Marketing, 72(2), 28-45. https://doi.org/10.1509/jmkg.72.2.28

Masoumi K, S. M., Abdul-Rashid, S. H., Olugu, E. U., \& Ghazilla, R. A. R. (2015). An integrated framework- for designing a strategic green supply chain with an application to the automotive industry. International Journal of Industrial Engineering, 22(1), 46-61.

Mello, J. E., \& Stank, T. P. (2005). Linking firm culture and orientation to supply chain 
success. International Journal of Physical Distribution \& Logistics Management, 35(8), 542-554. https://doi.org/10.1108/09600030510623320

Menguc, B. (2006). Creating a Firm-Level Dynamic Capability through Capitalizing on Market Orientation and Innovativeness. Journal of the Academy of Marketing Science, 34(1), 63-73. https://doi.org/10.1177/0092070305281090

Mentzer, J. T., Witt, W. De, Keebler, J. S., Min, S., Nix, N. W., Smith, C. D., \& Zacharia, Z. G. (2001). Defining supply chain management. Journal of Business Logistic, 22(1), 107124.

Min, S., \& Mentzer, J. T. (2004). Developing and measuring supply chain management concepts. Journal of Business Logistic, 25, 63-99.

Min, S., Mentzer, J. T., \& Ladd, R. T. (2007). A market orientation in supply chain management. Journal of the Academy of Marketing Science, 35(4), 507-522. https://doi.org/10.1007/s11747-007-0020-x

Miocevic, D., \& Crnjak-Karanovic, B. (2012). The mediating role of key supplier relationship management practices on supply chain orientation-The organizational buying effectiveness link. Industrial Marketing Management, 41(1), 115-124. https://doi.org/10.1016/j.indmarman.2011.11.015

Muhamed, A. A., Ab Rahman, M. N., Mohd Hamzah, F., Che Mohd Zain, C. R., \& Zailani, S. (2019). The impact of consumption value on consumer behaviour. British Food Journal, 121(11), 2951-2966. https://doi.org/10.1108/BFJ-10-2018-0692

Muhamed, A. A., Salim, N., Nizam, M., Rahman, A., Hamzah, M., \& Ali, M. H. (2020). Effects of supply chain orientation on firm performance : insights from a Malaysian case study of halal-certified small and medium-sized enterprises. Journal of Small Business \& Entrepreneurship, O(0), 1-17. https://doi.org/10.1080/08276331.2020.1848328

Muhammad, N. M. N., Isa, F. M., \& Kifli, B. C. (2009). Positioning Malaysia as Halal-Hub : Integration Role of Supply Chain Strategy and Halal Assurance System. Asian Social Science, 5(7), 44-52. https://doi.org/10.5539/ass.v5n7P44

Nasir, M., Norman, A., Fauzi, S., \& Azmi, M. (2011). An RFID-based validation system for Halal Food. International Arab Journal of Information Technology, 8(2), 204-211.

Ngah, A. H., Zainuddin, Y., \& Thurasamy, R. (2014a). Barriers and enablers in adopting Halal transportation services: A study of Malaysian Halal Manufacturers. International Journal of Business and Management, II(2).

Ngah, A. H., Zainuddin, Y., \& Thurasamy, R. (2014b). Modelling of Halal Warehouse Adoption Using Partial Least Squares. International Journal of Contemporary Business Management, 1(1), 71-86.

Ngah, A. H., Zainuddin, Y., \& Thurasamy, R. (2015). Barrier and Enabler in Adopting Halal Warehousing. Journal of Islamic Marketing, 6(3), 354-376.

Ngo, L. V., \& O'Cass, A. (2013). Innovation and business success: The mediating role of customer participation. Journal of Business Research, 66(8), 1134-1142. https://doi.org/10.1016/j.jbusres.2012.03.009

Noble, C. H., Sinha, R. K., \& Kumar, A. (2002). Market Orientation and Alternative Strategic Orientations: A Longitudinal Assessment of Performance Implications. Journal of Marketing, 66(4), 25-39. https://doi.org/10.1509/jmkg.66.4.25.18513

O'Regan, N., \& Ghobadian, A. (2005). Innovation in SMEs: the impact of strategic orientation and environmental perceptions. International Journal of Productivity and Performance Management, 54(2), 81-97. https://doi.org/10.1108/17410400510576595

Omar, E. N., \& Jaafar, H. S. (2011). Halal supply chain in the food industry - A conceptual 
model. ISBEIA 2011 - 2011 IEEE Symposium on Business, Engineering and Industrial Applications, SEPTEMBER 2011, 384-389. https://doi.org/10.1109/ISBEIA.2011.6088842

Paik, J., \& Chang, H. J. (2014). Open Innovation Strategies of Smartphone Manufacturers : External Resources and Network Positions. International Journal of Industrial Engineering, 21(5), 253-270.

Poniman, D., Purchase, S., \& Sneddon, J. (2015). Tracebility system in the Western Australia halal food supply chain. Asia Pacific Journal of Marketing and Logistic, 27(2), 324-348.

Porter, M. E. (1980). Competitive strategy: Technique for analyzing industries and competitors. New York Free Press.

Reefke, H., \& Trocchi, M. (2013). Balanced scorecard for sustainable supply chains: design and development guidelines. International Journal of Productivity and Performance Management, 62(8), 805-826. https://doi.org/10.1108/IJPPM-02-2013-0029

Rosly, S. A. (2010). Shariah parameters reconsidered. International Journal of Islamic and Middle Eastern Finance and Management, 3(2), 132-146. https://doi.org/10.1108/17538391011054372

Rugman, A. M., \& Verbeke, A. (1988). Does Competitive Strategy Work for Small Business? Journal of Small Business \& Entrepreneurship, 5(3), 45-50. https://doi.org/10.1080/08276331.1988.10600300

Salavou, H., Baltas, G., \& Lioukas, S. (2004). Organisational innovation in SMEs: The importance of strategic orientation and competitive structure. European Journal of Marketing, 38(9/10), 1091-1112. https://doi.org/10.1108/03090560410548889

Saunila, M., Pekkola, S., \& Uko, J. (2014). The relationship between innovation capability and performance: The moderating effect of measurement. International Journal of Productivity and Performance Management, 63(2), 234-249. https://doi.org/10.1108/LODJ-03-2012-0043

Seuring, S., \& Gold, S. (2012). Conducting content-analysis based literature reviews in supply chain management. Supply Chain Management: An International Journal, 17(5), 544555. https://doi.org/10.1108/13598541211258609

Slater, S. F., \& Narver, J. C. (2000). Intelligence Generation and Superior Customer Value. Journal of the Academy of Marketing Science, 28(1), 120-127. https://doi.org/10.1177/0092070300281011

Stanko, M. A., Bonner, J. M., \& Calantone, R. J. (2007). Building commitment in buyer-seller relationships: A tie strength perspective. Industrial Marketing Management, 36, 10941103. https://doi.org/10.1016/j.indmarman.2006.10.001

Stechemesser, K., \& Guenther, E. (2012). Carbon accounting: A systematic literature review. Journal of Cleaner Production, 36, 17-38. https://doi.org/10.1016/j.jclepro.2012.02.021

Svensson, G. (2007). Aspects of sustainable supply chain management (SSCM): conceptual framework and empirical example. Supply Chain Management: An International Journal, 12(4), 262-266. https://doi.org/10.1108/13598540710759781

Talib, M. S. A., \& Hamid, A. B. A. (2014a). External Factors Evaluation of Malaysia Halal Logistics Industry. International Conference on Innovation Driven Supply Chain, October.

Talib, M. S. A., \& Hamid, A. B. A. (2014b). Halal logistics in Malaysia: a SWOT analysis. Journal of Islamic Marketing, 5(3), 322-343. https://doi.org/10.1108/JIMA-03-20130018

Talib, M. S. A., Hamid, A. B. A., \& Chin, T. A. (2015). Motivations and limitations in 
implementing Halal food certification: a Pareto analysis. British Food Journal, 117(11), 2664-2705. https://doi.org/10.1108/BFJ-02-2015-0055

Talib, M. S. A., Hamid, A. B. A., \& Zulfakar, M. H. (2015). Halal supply chain critical success factor: a literature review. Journal of Islamic Marketing, 6(1), 44-71.

Talib, M. S. A., Hamid, A. B. A., Zulfakar, M. H., \& Chin, T. A. (2015). Barriers to Halal logistics operation: views from Malaysian logistics experts. International Journal of Logistics Systems and Management, 22(2), 193-209. https://doi.org/10.1504/IJLSM.2015.071545

Talib, M. S. A., \& Johan, M. R. M. (2012). Issues in Halal Packaging: A Conceptual Paper. International Business and Management, 5(2), 94-98. https://doi.org/10.3968/j.ibm.1923842820120502.1080

Tang, C. (2006). Robust strategies for mitigating supply chain disruptions. International Journal of Logistics, 9(1), 33-45. https://doi.org/10.1080/13675560500405584

Theodosiou, M., Kehagias, J., \& Katsikea, E. (2012). Strategic orientations, marketing capabilities and firm performance: An empirical investigation in the context of frontline managers in service organizations. Industrial Marketing Management, 41(7), 10581070. https://doi.org/10.1016/j.indmarman.2012.01.001

Tieman, M. (2011). The application of Halal in supply chain management: in-depth interviews. Journal of Islamic Marketing, 2(2), 186-195. https://doi.org/10.1108/17590831111139893

Tieman, M. (2012). Principles in halal supply chain management. Journal of Islamic Marketing, 3(3), 217-243. https://doi.org/10.1108/17590831211259727

Tieman, M. (2013a). Consumer perception on halal meat logistics. British Food Journal, 115(8), 1112-1129. https://doi.org/10.1108/BFJ-10/2011-0265

Tieman, M. (2013b). Establishing The Principles In Halal Logistics. Journal of Emerging Economies and Islamic Research, Vol.1, 1-13. http://www.jeeir.com/index.php/jeeir/article/view/32

Tieman, M. (2015). Halal clusters. Journal of Islamic Marketing, 6, 2-21. https://doi.org/10.1108/JIMA-05-2014-0034

Tieman, M., \& Ghazali, M. (2013). Principles in halal purchasing. Journal of Islamic Marketing, 4(3), 281-293. https://doi.org/10.1108/JIMA-01-2012-0004

Tieman, M., \& Hassan, F. H. (2015). Convergence of food systems: Kosher, Christian and Halal. British Food Journal, 117(9), 2313-2327. https://doi.org/10.1108/BFJ-02-20150058

Tieman, M., \& Nistelrooy, M. Van. (2014). Perception of Malaysian Food Manufacturers Toward Halal Logistics. Journal of International Food \& Agribusiness Marketing, 26(3), 218-233. https://doi.org/10.1080/08974438.2013.833572

Tranfield, D., Denyer, D., \& Smart, P. (2003). Towards a methodology for developing evidence-informed management knowledge by means of systematic review *. British Journal of Management, 14, 207-222. https://doi.org/10.1111/1467-8551.00375

Tutar, H., Nart, S., \& Bingöl, D. (2015). The Effects of Strategic Orientations on Innovation Capabilities and Market Performance : The Case of ASEM. Procedia-Social and Behavioral Sciences, 207, 709-719. https://doi.org/10.1016/j.sbspro.2015.10.144

Vlajic, J. V., Van Der Vorst, J. G. A. J., \& Haijema, R. (2012). A framework for designing robust food supply chains. International Journal of Production Economics, 137(1), 176-189. https://doi.org/10.1016/j.ijpe.2011.11.026

Wang, C.-H., Chang, C.-H., \& Shen, G. C. (2015). The effect of inbound open innovation on 
firm performance: Evidence from high-tech industry. Technological Forecasting \& Social Change, 99, 222-230. https://doi.org/10.1016/j.techfore.2015.07.006

Wang, Y.-M., Wang, Y.-S., \& Yang, Y.-F. (2010). Understanding the determinants of RFID adoption in the manufacturing industry. Technological Forecasting and Social Change, 77(5), 803-815. https://doi.org/10.1016/j.techfore.2010.03.006

Waters, D. (2007). Supply chain risk management : vulnerability and resilience in logistics. In Business. http://books.google.com/books?hl=en\&amp;|r=\&amp;id=-L9us3Nu2UC\&amp;oi=fnd\&amp;pg=PR5\&amp;dq=SUPPLY+CHAIN+RISk+MANAGEMENT++Vulnerability+and+Resilience+in+Logistics\&amp;ots=oUoR8k9nzf\&amp;sig=jUv2MW2 R1nmjUm0jVUBNGEmBBSo

Wei, Z., Zhao, J., \& Zhang, C. (2014). Organizational ambidexterity, market orientation, and firm performance. Journal of Engineering and Technology Management, 33, 134-153. https://doi.org/10.1016/j.jengtecman.2014.06.001

Wilson, J. A. J., \& Liu, J. (2010). Shaping the Halal into a brand? Journal of Islamic Marketing, 1(2), 107-123. https://doi.org/10.1108/17590831011055851

Wimalachandra, D. C., Frank, B., \& Enkawa, T. (2014). Strategic openness in quality control: Adjusting NPD strategic orientation to optimize product quality. International Journal of Industrial Engineering : Theory Applications and Practice, 21(6), 348-359.

Wisner, J. D. (2003). A Structural Equation Model of Supply Chain Management Strategies and Firm Performance. Journal of Business Logistics, 24(1), 1-26. https://doi.org/10.1002/j.2158-1592.2003.tb00030.x

Witell, L., Snyder, H., Gustafsson, A., Fombelle, P., \& Kristensson, P. (2016). Defining service innovation: A review and synthesis. Journal of Business Research. https://doi.org/10.1016/j.jbusres.2015.12.055

Wu, M. Y., \& Ku, C. W. (2013). A study of key factors in the introduction of rfid into supply chains through the adaptive structuration theory. International Journal of Industrial Engineering: Theory Applications and Practice, 20(5-6), 429-443.

Zailani, S., Kanapathy, K., Iranmesh, M., \& Tieman, M. (2015). Drivers of halal orientation strategy among halal food firms. British Food Journal, 117(8), 148-163. https://doi.org/10.1108/BFJ-01-2015-0027

Zarco, A. I. J., Ruiz, M. P. M., \& Yusta, A. I. (2011). The impact of market orientation dimension on client cooperation in the development of new service innovations. European Journal of Marketing, 45(1/2), 43-67.

Zhou, K. Z., Yim, C. K., \& Tse, D. K. (2005). The Effects of Strategic Orientations on Technology- and Market-Based Breakthrough Innovations. Journal of Marketing, 69(2), 42-60. https://doi.org/10.1509/jmkg.69.2.42.60756 